\title{
Evaluation of the Vegetation Period According to Climate Change Scenarios: A Case Study in the Inner West Anatolia Subregion of Turkey*
}

\section{Vejetasyon Döneminin İklim Değişimi Senaryolarına Göre Değerlendirilmesi: İç Batı Anadolu Bölümü Örneği}

\author{
Taner SAR ${ }^{1}$ (D), Sedat AVCI ${ }^{1}$ (D), Meral AVCI ${ }^{1}$ (D) \\ ${ }^{1}$ Istanbul University, Department of Geography, Division of the Climate Change, Istanbul, Turkey
}

ORCID: T.S. 0000-0003-2369-9638; S.A. 0000-0003-4371-5578; M.A. 0000-0003-4367-3021

\begin{abstract}
In this research, 15 meteorological stations located in western Anatolia in Turkey were investigated for determining temperature properties. The vegetation season has been determined according to days when the daily temperature was greater than or equal to $8^{\circ} \mathrm{C}$. The research area has 3 different vegetation durations as longer (more than 225 days in the western and southern parts), moderate (210-220 days in plateaus around Uşak, Gediz and Demirci), and shorter (180-195 days in the eastern part and less than 180 days in mountainous areas). Then, the vegetation has been reinvestigated according to climate change scenarios (RCP 4.5 and 8.5). For this purpose, the daily mean temperatures were raised by $2.6^{\circ} \mathrm{C}$ and $4.8^{\circ} \mathrm{C}$ for $\mathrm{RCP} 4.5$ and $\mathrm{RCP} 8.5$, respectively. In the reinvestigation period, the vegetation period will increase about 15-20 days or over 40 days according to RCP 4.5 and 8.5 , respectively. Along with the increase in temperature throughout the research area, growing seasons will be significantly affected, beginning and ending dates of vegetation would shift. Owing to climate change effects, mountainous areas may be affected more than low altitude areas. As a conclusion due to the result of increasing temperature, plant development and distribution will be affected, and new plant species may occur.
\end{abstract}

Keywords: Growing seasons, climate change scenarios, Turkey

Öz

Araştırma alanı Türkiye'nin batısında yer alan İç Batı Anadolu Bölümüdür. Bu çalışmada bölümün sıcaklık özelliklerinin belirlenmesi için 15 farklı meteoroloji istasyonun verileri kullanılmıştır. Vejetasyon dönemi, günlük sıcaklık değerlerinin $8^{\circ} \mathrm{C}$ ve üzerinde olan gün sayısına göre belirlenmiştir. Araştırma alanında kısa (doğuda 180-195 gün arasında ve dağlık alanlarda 180 günün altında), orta (Uşak, Gediz ve Demirci platoları civarında 210-220 gün) ve uzun (batıda ve güneyde 225 günün üzerinde) dönem olmak üzere 3 farklı vejetasyon döneminin olduğu görülmüştür. Ayrıca, vejetasyon dönemi iklim değişimi senaryolarına (RCP 4.5 ve 8.5) göre yeniden belirlenmiştir. Bunun için günlük ortalama sıcaklıklar RCP 4.5 ve 8.5 senaryolarına göre sırasıyla $2.6^{\circ} \mathrm{C}$ ve $4.8^{\circ} \mathrm{C}$ arttırılmıştır. İklim değişimi etkileri ile günlük ortalama sıcaklıklar tekrardan incelendiğinde, vejetasyon süresinde RCP 4.5 senaryosuna göre $15-20$ gün, 8.5 senaryosuna göre ise 40 günün üzerinde artış olabilir. Araştırma alanında bu sıcaklık artışları ile vejetasyon devresi önemli olarak etkilenebilir, vejetasyon döneminin başlangıcı ve sona erme tarihlerinde kaymalar olabilir. İklim değişimi etkisi yükseltisi az olan alanlara göre en çok dağlık alanlarda hissedilebilir. Bu çalışmanın sonucuna göre, araştırma alanındaki sıcaklık artışı bitkilerin gelişimi ile dağılışını etkileyebilir ve bu sahalara yeni bitki türleri de sokulabilir.

Anahtar kelimeler: Vejetasyon dönemi, iklim değişimi senaryoları, Türkiye

*This paper has been developed from the master thesis work of the first author.

Submitted/Başvuru: 03.07.2019 • Revision Requested/Revizyon Talebi: 24.08.2019 • Last Revision Received/Son Revizyon: 28.08 .2019 • Accepted/Kabul: 09.09.2019 Published Online/Online Yayın: 21.11.2019

Corresponding author/Sorumlu yazar: Taner SAR / tsar@gtu.edu.tr

Citation/Atıf: Sar, T., Avci, S., Avci, M. (2019). Evaluation of the vegetation period according to climate change scenarios: A case study in the Inner West Anatolia Subregion of Turkey. Cografya Dergisi, 39, 29-39. https://doi.org/10.26650/JGEOG2019-0018 


\section{INTRODUCTION}

During the nearly 4,5 billion years of Earth's history, the climate systems tend to change from a million years to ten years. The most obvious climate changes have occurred at the interglaciers-glacier cycle in the Quaternary. Since the 19th century, climate changes have been introduced a new period with anthropogenic effects except natural effects. Today, it can be observed that permanent snow-glacial melts and the increase in the global average sea level due to increasing global air and ocean temperatures (IPCC, 2007). Recent changes in climate have caused changes in vegetation. Complexity of the vegetation and climate interactions make predicting the outcomes of climate change on vegetation difficult (Ackerly et al., 2010, Angert, LaDeau, \& Ostfeld, 2013, Svenning \& Sandel, 2013, Svenning et al., 2015). In recent years, many authors have been interested in the effects on vegetation and crop yields via climate change scenarios (RCP, Representative Concentration Pathways). Four different climate change scenarios were presented in the Intergovernmental Panel on Climate Change report (IPCC, 2013). According to the most optimistic scenario (RCP 2.6), the average global greenhouse emissions will increase to a certain point and after that, these levels will decrease. According to RCP 4.5 and 6.0 scenarios, the increase will continue until 2040 and 2080, respectively. Moreover, according to the worst scenario RCP 8.5, emissions will regularly continue to increase over the 21st century (Meinshausen et al., 2011; IPCC, 2013).

\subsection{The Inner West Anatolia Subregion}

Turkey is divided into seven geographical regions. One of them is the Aegean Region. The Aegean Region is surrounded by the Marmara Region to the north, the Mediterranean Region to the south, the Central Anatolia Region to the east, and the Aegean Sea to the west (Figure 1a). The Aegean Region is divided into two subregions which are the Main Aegean Subregion and the Inner West Anatolia Subregion (Figure 1a,b). The Main Aegean Subregion is under more prominent marine effects while the Central Anatolia Region has more continental conditions. The Inner West Anatolia Subregion is a transition area between the Main Aegean Subregion and the Central Anatolia Region, in terms of climatic conditions. This subregion consists of mountains stretching from northwest to southeast in several ranges (Darkot \& Tuncel, 1995). More than $60 \%$ of the subregion has moderate altitude ranging from $750 \mathrm{~m}$ to $1250 \mathrm{~m}$. The high altitude areas (up to $1750 \mathrm{~m}$; Murat Mountain 2309 m, Şaphane Mountain 2120 m, Simav Mountain 2089 m, Emir Mountain $2307 \mathrm{~m}$ ) are around 1\% (Elibüyük \& Yilmaz, 2010).

Pinus nigra, Populus tremula and Pinus sylvestris have been widely found in the research area. The distribution areas of the Pinus nigra are above 800-900 m (e.g. Dursunbey Mountain, Alaçam Mountain, Şaphane Mountain, and Beşparmak Mountains). Ulmus sp., Juniperus sp. and some oak species (Quercus cerris, Q. pubescens, and Q. infectoria) are also distributed among the Pinus nigra. Some juniper species ( $J$. excels and $J$. foetidissima) are also found as communities on the south-facing slopes of the mountainous areas around Denizli, Afyonkarahisar and Kütahya (Günal, 1986; Günal, 1997; Y1lmaz, 2001; Günal, 2003; Günal, 2013). Some humid forest species such as Fagus orientalis, Carpinus betulus, Acer platanoides, Acer hyrcanum subsp. keckianum, Tilia rubra subsp.caucasica, Castanea sativa, Tilia cordata, Acer campestre, Corylus avellana, Carpinus betulus, and Sorbus torminalis have spread in the higher precipitation areas (Dönmez, 1972, Günal, 1986; Günal, 1997; Günal, 2003; Günal, 2013).

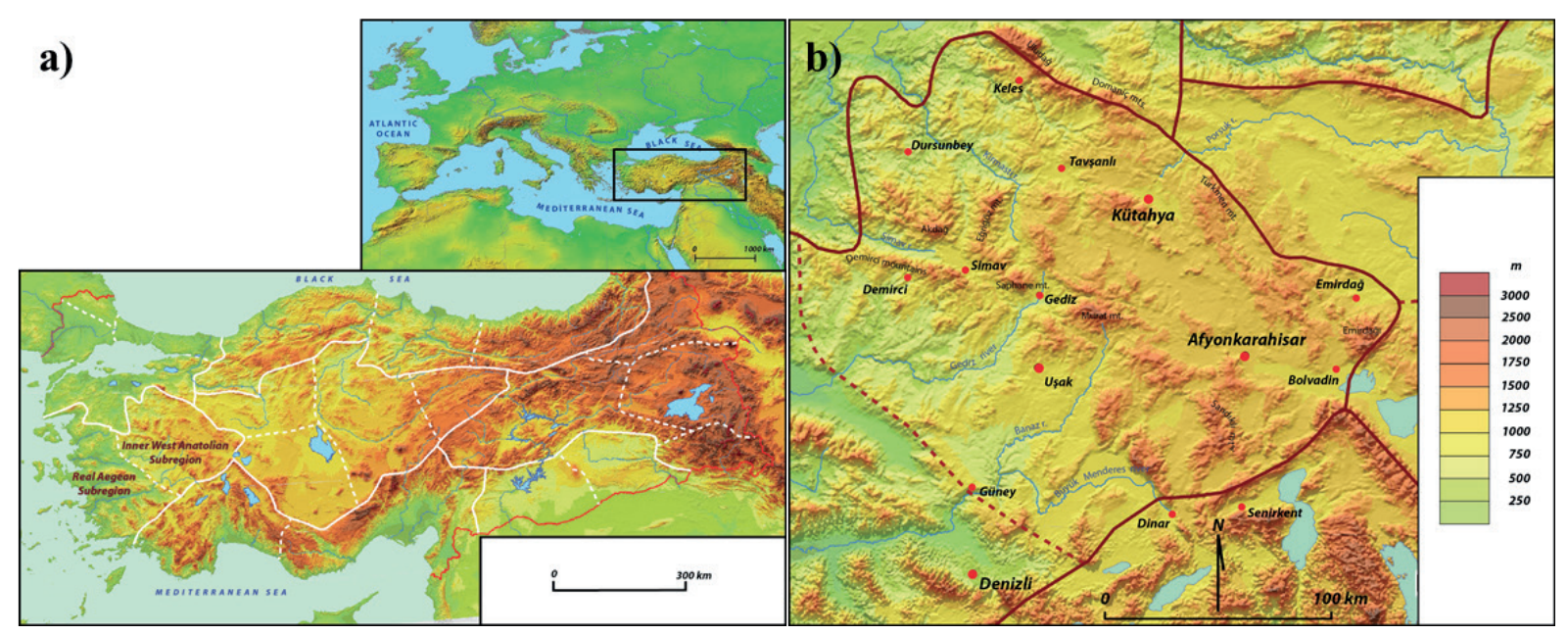

Figure 1: The location map of the study area (the Inner West Anatolia Subregion of Turkey). 
In this work, 4 different questions can be created:

1. When does the vegetation period start in the Inner West Anatolia Subregion by current climate data?

2. When does the vegetation period end in this research area by current climate data?

3. How long is the vegetation period in the research part by the current climate features?

4. How will the vegetation period change at the start and end of the growing season, and also vegetation duration according to climate change scenarios which are RCP 4.5 and 8.5 ?

The aim of this study is to investigate the effects of climate change in the Inner West Anatolia Subregion which is in the western part of Turkey. In addition, it aims to estimate the changes in both vegetation period, and the beginning and the end of the growing season according to some climate change scenarios (RCP 4.5 and RCP 8.5).

\section{METHODS}

\subsection{The Location of Research Area}

The Inner West Anatolia Subregion (Figure 1b) covers an area of $37,800 \mathrm{~km}^{2}$ in the inner west of Turkey (Elibüyük \& Y1lmaz, 2010), ranging from $37^{\circ} 50^{\prime}$ to $40^{\circ} 07^{\prime} \mathrm{N}$ and from $28^{\circ} 50^{\prime}$ to $31^{\circ} 24^{\prime} \mathrm{E}$.

\subsection{The Analysis of Temperature}

In this work, the climate data (temperature) recorded from 15 stations (Table 1) was provided by the Turkish State Meteorological Service (Ankara, Turkey).

Table 1. The meteorological stations used in the research area, the elevation of the stations and the range dates of the climate data.

\begin{tabular}{ccc}
\hline Meteorological Stations & Altitude $(\mathbf{m})$ & Period \\
\hline Afyonkarahisar & 1034 & $1960-2016$ \\
Bolvadin & 1018 & $1968-2016$ \\
Demirci & 855 & $1991-2016$ \\
Denizli & 425 & $1960-2016$ \\
Dinar & 864 & $1960-2016$ \\
Dursunbey & 637 & $1965-2016$ \\
Emirdağ & 983 & $1964-2016$ \\
Gediz & 736 & $1972-2016$ \\
Güney & 825 & $1964-2016$ \\
Keles & 1063 & $1965-2016$ \\
Kütahya & 969 & $1960-2016$ \\
Senirkent & 959 & $1966-2016$ \\
Simav & 809 & $1960-2016$ \\
Tavşanlı & 833 & $1965-2016$ \\
Uşak & 919 & $1960-2016$ \\
\hline
\end{tabular}

The research area's altitude has generally $1000 \mathrm{~m}$. The altitudes of the meteorological stations (Table 1) in the research area have generally ranged from $425 \mathrm{~m}$ (Denizli) and $1063 \mathrm{~m}$ (Keles). On the other hand, some areas' altitudes are also higher than 2000 m (i.e. Murat Mountain 2309 m, Şaphane Mountain 2120 m, Emir Mountain 2307 m). For determining the climate properties of different altitudes which are devoid of meteorological stations, it was determined through the following interpolation formula (Fairbridge \& Oliver, 2005);

$$
\mathrm{T}_{r}=\mathrm{T}_{i} \pm\left(\mathrm{h}_{i} * 0.005\right)
$$

In this formula, $\mathrm{T}_{r}$ represents the temperature according to different altitudes to be determined, $\mathrm{T}_{i}$ is the mean temperature of the meteorological stations, $\mathrm{h}_{i}$ shows the altitude of the point to be calculated.

\subsection{Determination of Frost Days and Tropical Night Temperatures}

The temperature indices (frost days and tropical nights) have been determined through the formula by Expert Team on Climate Change Detection and Indices (ETCCDI) and calculated by R-based software (RClimDex) (Zhang \& Yang, 2004).

The Expert Team formula calculation depends on the following: a- The number of frost days is the annual count of days when the daily minimum temperature $(\mathrm{TN})$ is less than $0^{\circ} \mathrm{C}$. Let $\mathrm{TN}_{i j}$ be daily minimum temperature on day $i$ in year $j$. Count the number of days where $\mathrm{TN}_{i j}<0^{\circ} \mathrm{C}$.

b- The number of tropical nights is the annual count of days where $\mathrm{TN}$ is higher than $20^{\circ} \mathrm{C}$. Let $\mathrm{TN}_{i j}$ be the daily minimum temperature on day $i$ in period $j$. Count the number of days where $\mathrm{TN}_{i j}>20^{\circ} \mathrm{C}$.

\subsection{Determination of Vegetation Period}

The vegetation period was evaluated to the average daily temperature accepted threshold. According to some authors, this accepted threshold value was set up to $+5.0^{\circ} \mathrm{C}$ (Erinç, 1984; Primault, 1992), or $+8.0^{\circ} \mathrm{C}$ (Atalay, 1994), or $+10.0^{\circ} \mathrm{C}$ (Dönmez, 1985). Moreover, most of the authors interested in plant geography have accepted that the vegetation period may represent when the temperatures are higher than $+8^{\circ} \mathrm{C}$ (Leibundgut, 1970; Avc1, 1990; Engin, 1992; Aktaş, 1992; Güngördü, 1993; Avc1, 1997; Avc1, 1998). Thereby, in this study, the vegetation period was determined according to the daily temperature being greater than or equal to $8^{\circ} \mathrm{C}$. 


\subsection{Evaluation of Climate Change Scenarios}

It has been estimated that the average surface temperature for the end of the 21 st century will increase up to $2.6-4.8^{\circ} \mathrm{C}$ according to Fifth Assessment Report (AR5) announced by IPCC 2013. For the evaluation of the effect of global temperature increase on the vegetation period, it was assessed that daily average temperature data was increased by $2.6^{\circ} \mathrm{C}$ and $4.8^{\circ} \mathrm{C}$ according to the RCP 4.5 and the RCP 8.5 scenarios, respectively (Van Vuuren et al. 2011). And then, the vegetation period was reevaluated according to the RCP 4.5 and the RCP 8.5 scenarios (Şar, 2018).

\subsection{Drawing the Maps}

The maps of location, distributions of temperature, vegetation period, and the beginning and the end of the growing season were prepared by using the ArcGIS 10.2 programme (ESRI, 2013). The spatial resolution is 250 meters.

\section{RESULTS and DISCUSSIONS}

\subsection{Temperature}

The mean annual temperature of the meteorological stations located in the research area was determined by using the climate data (Table 1).

In the research area, the mean annual temperature ranges from $10^{\circ} \mathrm{C}$ to $14^{\circ} \mathrm{C}$ (Figure 2a). These temperature values are generally slightly lower in the north (e.g. Keles $9.7^{\circ} \mathrm{C}$ ), higher in the south (e.g. Denizli $\left.16.3^{\circ} \mathrm{C}\right)$. Whereas the lowest temperatures are seen in January (Figure 2b), the highest temperatures are seen in July
(Figure 2c). January temperatures representing the cold period are less than $1^{\circ} \mathrm{C}$ in the north and the east (e.g. Keles $0.3^{\circ} \mathrm{C}$, Kütahya $0.5^{\circ} \mathrm{C}$, Afyonkarahisar $0.4^{\circ} \mathrm{C}$ ). These cold temperatures are hotter in the west and the south (i.e. up to $3^{\circ} \mathrm{C}$; e.g. Demirci $3.8^{\circ} \mathrm{C}$, Güney $3.6^{\circ} \mathrm{C}$, Denizli $5.9^{\circ} \mathrm{C}$ ). July temperatures representing the hot season are also less than $20.0^{\circ} \mathrm{C}$ in the north (Keles $19.3^{\circ} \mathrm{C}$ ), generally ranged between $21.0-23.0^{\circ} \mathrm{C}$ in the east (Kütahya $21.0^{\circ} \mathrm{C}$, Afyonkarahisar $22.3^{\circ} \mathrm{C}$, Emirdağ $22.9^{\circ} \mathrm{C}$ ), and up to $24^{\circ} \mathrm{C}$ in the west and the south (Demirci $24.4^{\circ} \mathrm{C}$, Güney $24.7^{\circ} \mathrm{C}$, Denizli $27.6^{\circ} \mathrm{C}$ ).

\subsubsection{Frequencies of Frost days}

Distribution and development of plant species is mainly affected by temperature as an environmental factor (Mittler, 2006). The yield of economic crops like wheat could be decreased due to lower temperatures during the spring and winter (Porter \& Gawith, 1999; Frederiks et al., 2012). Similarly, frost could damage flower buds and seeds during the vegetation period (Inouye, 2008). Therefore, the number and frequency of frost days in the research area have been determined.

The frequency of frost days in the research area has shown no significant change between 1975 and 2015 (Figure 3). However, the frost days are slightly increased during the period 1975-1991 (Figure 3), and these changes were more common in spring (especially in May). This situation might have damaged to plant phenology. Moreover, it is an important point that the frost days have gradually decreased since 1991 (Figure 3). Similarly, frost days during the growing season in Eurasia including Europe and central Siberia increased between the 1980s and the 1990s and then decreased between the 1990s and the 2000s (Liu et al., 2018). In the future, the frost days in the Inner West Anatolian Subregion will continue to decrease due to global warming.

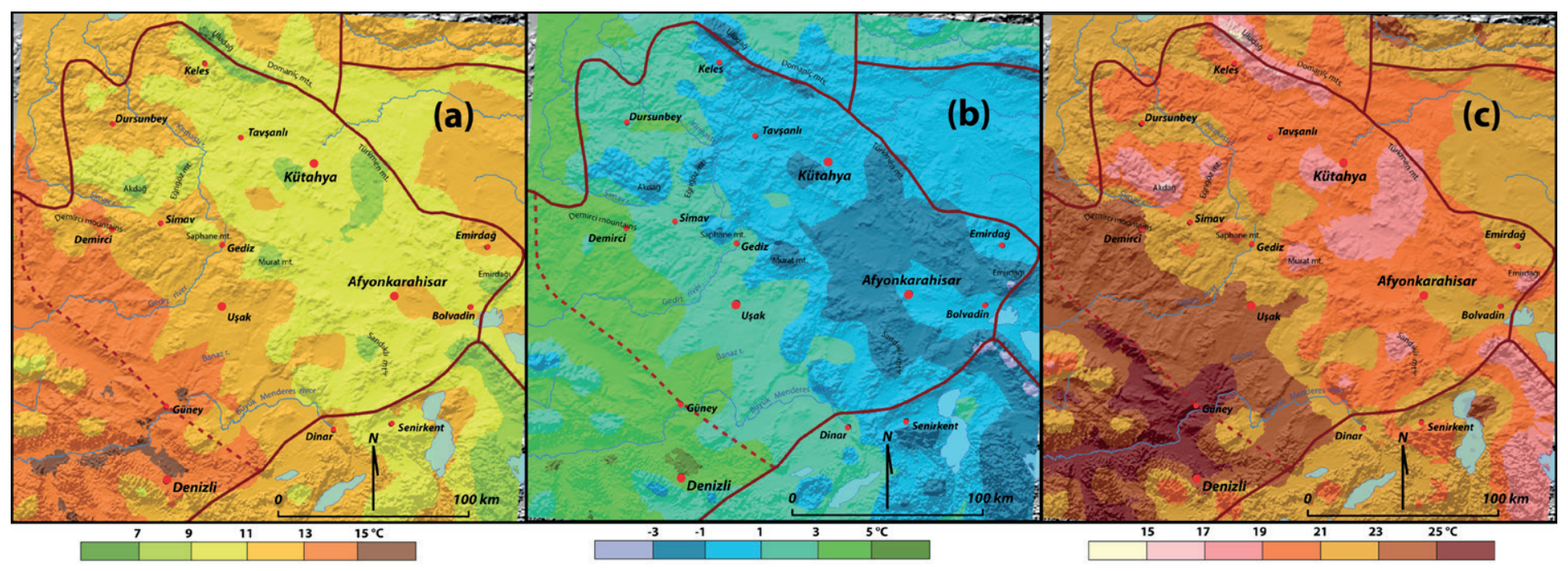

Figure 2: The distribution of the temperatures: (a) Annual, (b) January, and (c) July. 


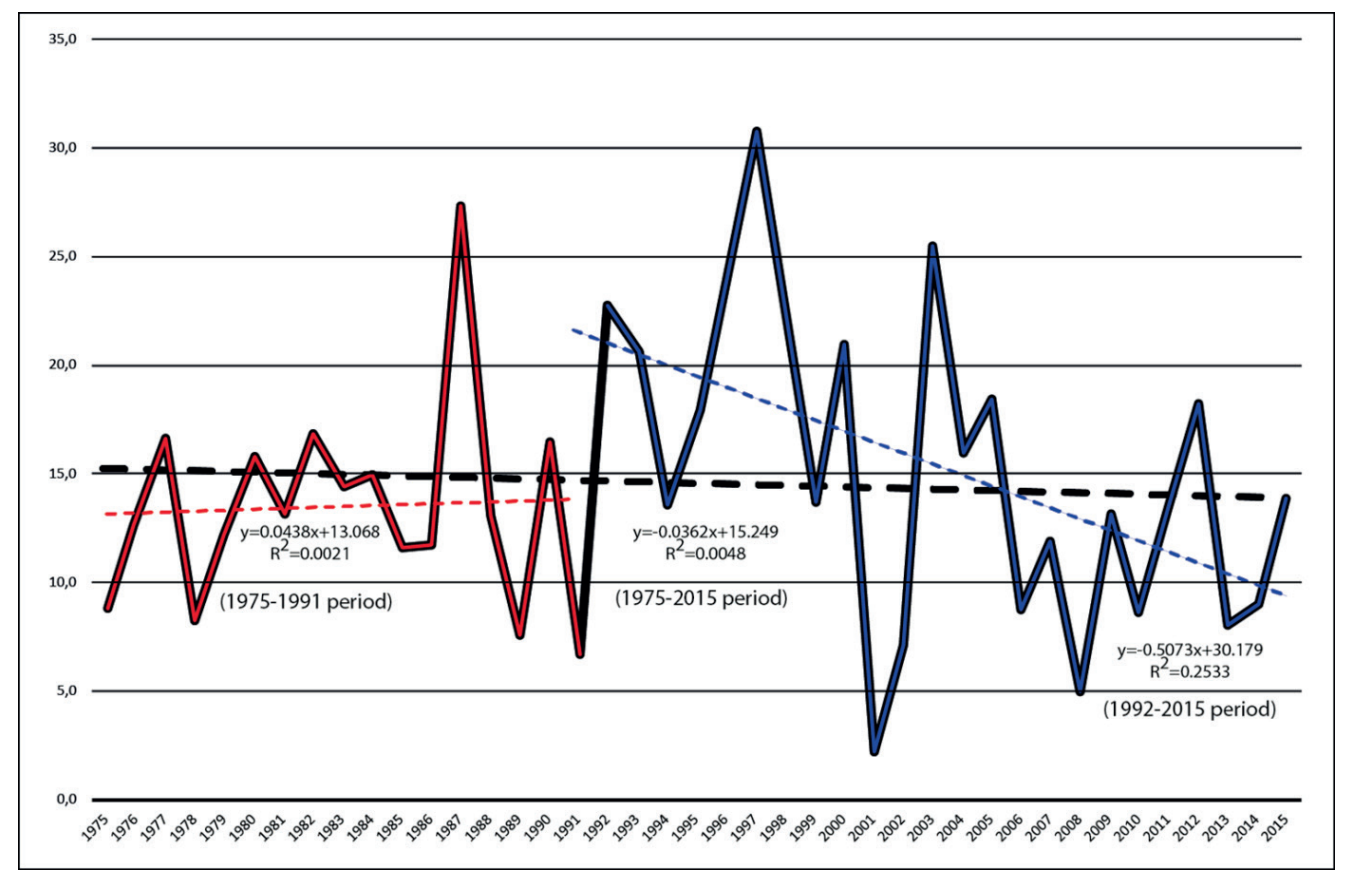

Figure 3: The frequencies of the frost days in the Inner West Anatolia Subregion.

\subsubsection{Frequencies of Tropical Night Temperatures}

Extreme temperatures (high temperature and drought) are mainly abiotic stress potentially causing the reactive oxygen species (ROS) accumulation and cellular damage and photosynthesis inhibition (Zandalinas et al., 2018). This situation affects Photosystem II (PSII), ribulose-1,5-bisphosphate carboxylase/oxygenase (Rubisco), Cytochrome b559 (Cytb559) and plastoquinone (PQ) (Mathur, Agrawal, \& Jajoo, 2014). Therefore, the number and distribution of tropical night temperatures in the research area have been investigated for possible effects on plant development.
Different types of scenarios about climate change have indicated that the beginning and the end of the vegetation period will be changed. Though the vegetation period has not been affected by the frost days occurred except vegetation period, it will be affected from the tropical night temperature because of appearance in the vegetation season. For this reason, the number and frequencies of tropical night temperatures have been evaluated in the research area. While the tropical night temperatures have not been seen in the eastern and northern areas, they have been gradually increasing in the southern and western parts (Denizli, Güney, and Demirci; Figure 4). This event has been generally in July-August, and possibly seen in

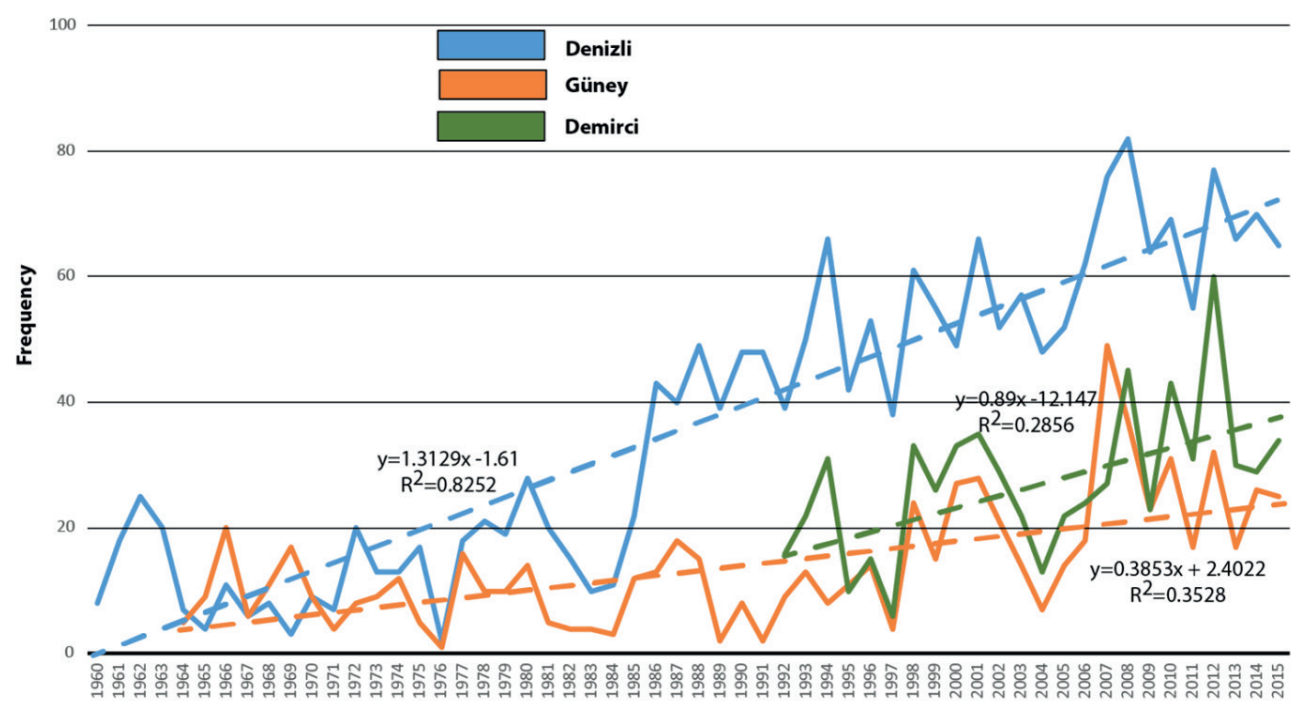

Figure 4: The frequencies of the tropical night temperatures in Denizli, Güney, and Demirci. 
May and June. Owing to the occurrence in the vegetation season, the frequency of tropical night temperatures could be important for vegetation particularly in the western and southern parts. Similarly, the obtained results are also consistent with previous studies (Erlat \& Türkeş, 2017).

\subsection{Vegetation}

\subsubsection{Distribution of the Vegetation Period}

Temperature is the most important parameter affecting plant growth. Photosynthesis, organ development and growth, dry matter production and distribution mainly depend on the temperature (Mazurczyk, Lutomirska, \& Wierzbicka, 2003; Kläring et al., 2015; Körner, 2015; Lizana et al., 2017). On the other hand, the temperature characteristics of an environment are also connected with the vegetation period; thereby it is very important for plant development (An et al., 2018).

When the distribution of the vegetation period map in the research area (Figure 5) was analyzed, it was clearly shown that there are 3 different vegetation characteristic zones for the duration of the vegetation period. The vegetation period has
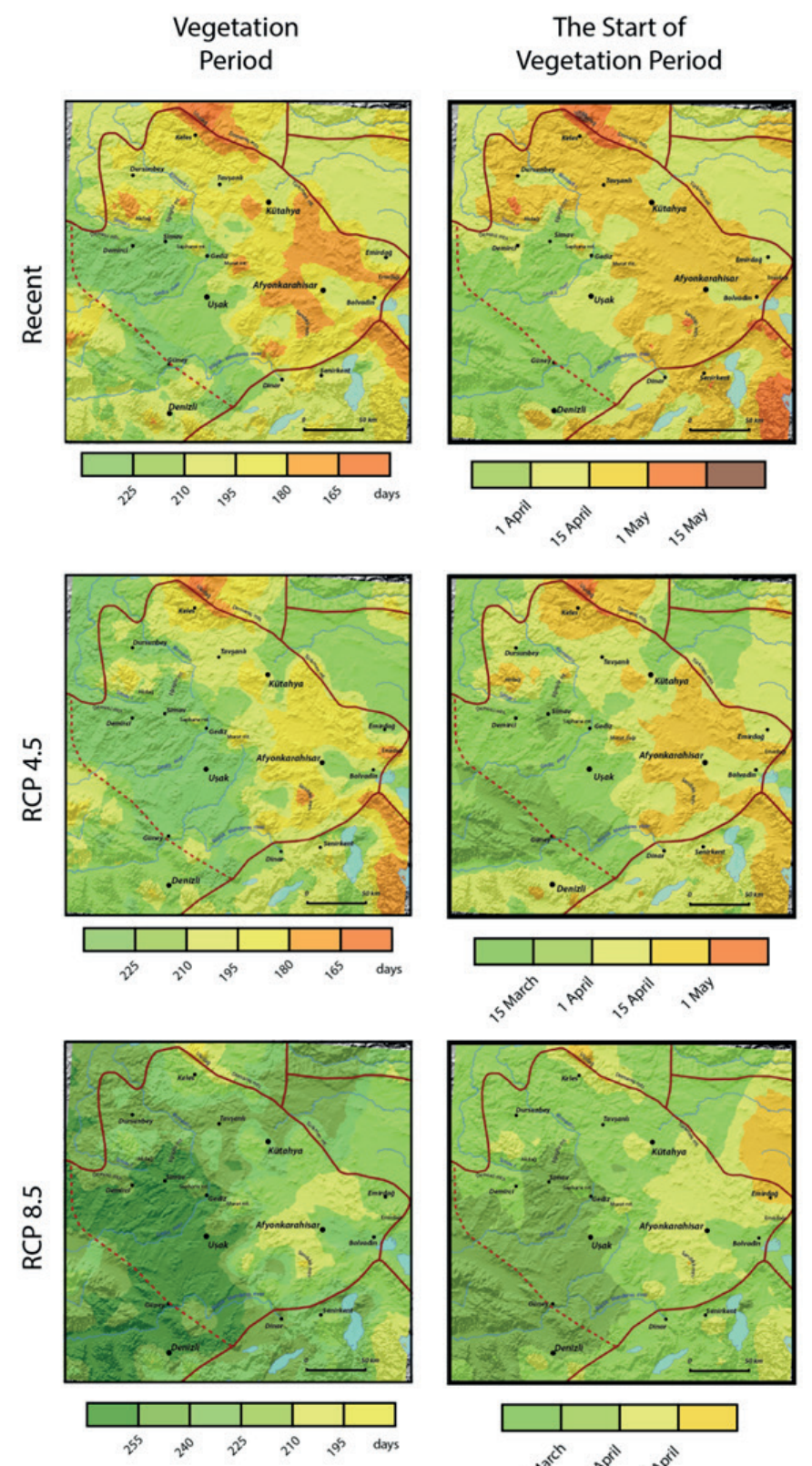
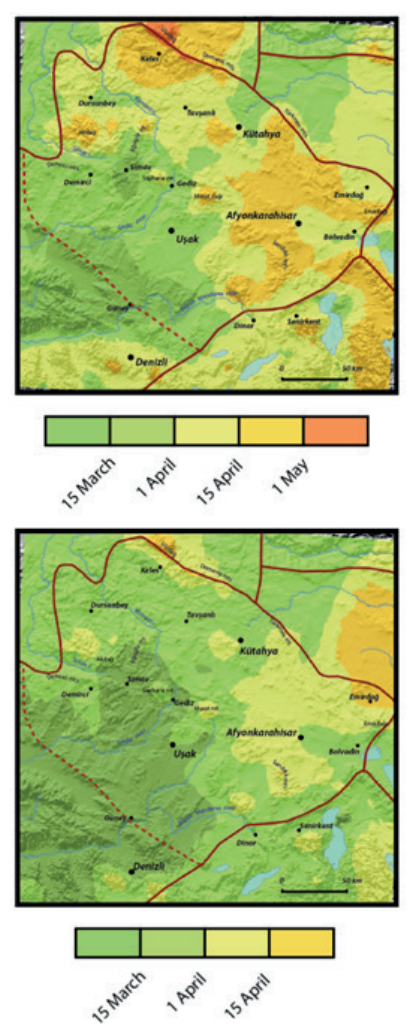

The End of Vegetation Period
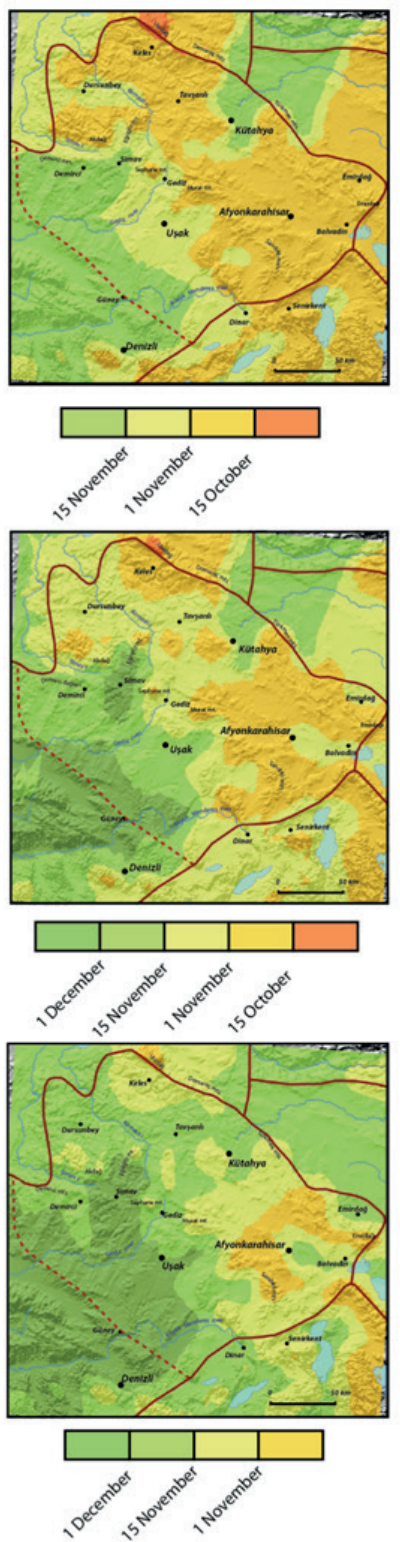

Figure 5: The distribution of the vegetation period, the start and the end of vegetation period according to recent and climate change scenarios (RCP 4.5 and RCP 8.5). 
ranged between 165 days and 225 days (5.5-7.5 months). The longest vegetation period is in the west and south parts of the research area, which are lower in altitude than others. Especially, this duration has reached 250 days in the low areas that make up the Gediz and Büyük Menderes Rivers. These areas, are surrounded with maquis and other Mediterranean's plants that demand higher temperatures. Contrarily, the vegetation period has decreased to 210 days (7 months) around the Uşak plateaus and the mountainous areas among the Büyük Menderes River and Ac1 Lake. These areas constitute the areas where the plants that reflect the warmer and the arid conditions of the Mediterranean have been largely eliminated (Avc1, 1995).

The duration of vegetation in the east has less than 195 days (6.5 months) (e.g. low altitude around Tavşanlı, AfyonkarahisarBolvadin, Porsuk River valley located in the eastern Kütahya). In the higher altitudes, vegetation has been less than 180 days (6 months) (e.g. high parts of Emir Mountain, Yellice Mountain, Gümüş Mountain, and Türkmen Mountain). Pinus nigra and Juniper sp. communities dominate these areas.

\subsubsection{The Beginning of the Vegetation Period}

It has been seen that some marked differences between eastern and western part of the research area for beginning of the vegetation (Figure 5). The vegetation period starts the earliest in the valleys and plains located in the west and the south. The vegetation period in the west has started in the last week of March or the first week of April. On the other hand, when going from the west to the east, the beginning of the growing season has extended due to rising altitude areas. The beginning of the vegetation period in the high-altitude areas (the eastern part) has begun from the first half of May.

\subsubsection{The End of the Vegetation Period}

The end of the vegetation period in the Inner West Anatolia Subregion has similar behavior with the beginning of the growing season (Figure 5). The end of the vegetation period has continued to half of November in the west and the south. The end of the growing season around the plateaus areas around Uşak is relatively earlier than the west and the south. Contrarily, the end of the vegetation period in the east has been a month earlier than in the west. Especially, the vegetation in the higher altitudes areas have ended after half of October (e.g. Murat Mountain, Emir Mountain, Türkmen Mountain, and Domaniç Mountain).

\subsection{The Climate Change}

Today, the warming has been clearly seen by observing the increase average global air and ocean temperatures, the melting of snow-glacial, and the rise in global average sea levels (IPCC, 2007). The effects of climate change on RCP scenarios and climate change models, plant vegetation period and plant crop yield have been investigated in various studies (Pauli, Gottfried, \& Grabherr, 2014; Ackerly et al., 2015; Wu et al., 2015; Scheiter \& Savadogo, 2017; Werner et al., 2017; Schmid et al., 2018). Although many climate change models have been prepared intended for Turkey's future (Table 2), vegetation period, plant crop yield or related studies according to climate change effects conducted in Turkey have been quite limited (Ozkan \& Akcaoz, 2002; Yano, Aydin, \& Haraguchi, 2007; Özdoğan, 2011). For this reason, this work investigates how the vegetation period will be affected considering possible climate change scenarios (RCP 4.5 and RCP 8.5) and via climate change models conducted in Turkey (Table 2).

\subsubsection{Evaluation the Vegetation Period According to Climate Change Scenario RCP 4.5}

It has been seen that the vegetation period has some differences among the current and RCP 4.5 scenario (Figure 5). The vegetation period in the Kirmasti stream located north of the research area, and in the north of Gediz and Büyük Menderes Rivers may extend up to 210 days ( 7 months), and this period may reached 240 days (8 months) in some areas. Surprisingly, it has been estimated that the vegetation period in the eastern part will undergo a prominent change. The vegetation may increase from 165-195 days (i.e. 5.5 - 6.5 months) to 180-210 days (i.e. 6 -7 months). There is a possibility of roughly 15 days of significant elongation. Moreover, the vegetation period in the mountainous areas (especially around Kütahya and Afyonkarahisar) will be longer at least 2-3 weeks. According to the RCP 4.5 scenario, the most increased heating areas will be low altitude areas such as plains and valleys (e.g. Afyonkarahisar and Bolvadin Plains). The vegetation period in these areas may be extended by at least 3 weeks according to the RCP 4.5 scenario.

In the western part, the increase in temperature values indicates that the vegetation may begin from the beginning of March. In the eastern part of the research area, it will be seen that the vegetation period will begin after the half of April in some areas (especially around Dursunbey, Tavşanlı, Kütahya, and Afyonkarahisar). This state indicates that the vegetation period will start earlier by at least 15 days in many places. Therefore, 
Table 2. Some climate change models associated with Turkey for the future.

\begin{tabular}{|c|c|c|c|c|}
\hline Location & $\begin{array}{l}\text { Temperature anomaly } \\
\text { changes }\end{array}$ & $\begin{array}{l}\text { Climate Change Scenarios } \\
\text { or Climate Models }\end{array}$ & Period & Reference \\
\hline Europe (Especially Southern & $+3^{\circ} \mathrm{C}$ & RCP 8.5 & $2040-2069$ & Fortems-Cheiney et al., 2017 \\
\hline Europe including Turkey) & $+2^{\circ} \mathrm{C}$ & RCP 4.5 & $2028-2057$ & \\
\hline \multirow[t]{2}{*}{ Adana (Turkey) } & $\begin{array}{l}+4.3^{\circ} \mathrm{C} \\
+5.3^{\circ} \mathrm{C}\end{array}$ & $\begin{array}{l}\text { CGCM2 } \\
\text { ECHAM4 }\end{array}$ & \multirow[t]{2}{*}{2100} & \multirow[t]{2}{*}{ Yano, Aydin, \& Haraguchi 2007} \\
\hline & $+3.1^{\circ} \mathrm{C}$ & MRI & & \\
\hline \multirow[t]{2}{*}{ Seyhan River (Adana, Turkey) } & +2.0 & MRI & \multirow[t]{2}{*}{$2070 \mathrm{~s}$} & \multirow[t]{2}{*}{ Fujihara et al., 2008} \\
\hline & $+2.7^{\circ} \mathrm{C}$ & CCSR & & \\
\hline Eskişehir, Turkey & $+3.1^{\circ} \mathrm{C}$ & $\begin{array}{l}\text { Hydrological } \\
\text { Simulation Program }\end{array}$ & $2050 \mathrm{~s}$ & Albek et al., 2014 \\
\hline \multirow{3}{*}{$\begin{array}{l}\text { Hayrabolu } \\
\text { (Thrace, the Northwest of Turkey) }\end{array}$} & +1.1 to $+3^{\circ} \mathrm{C}$ & ECHAM4 & 2025 & \multirow[t]{3}{*}{ Aksoy et al., 2008} \\
\hline & $+2.1^{\circ} \mathrm{C}$ & & 2050 & \\
\hline & $+4.3^{\circ} \mathrm{C}$ & & 2100 & \\
\hline \multirow[t]{2}{*}{ Western Turkey } & +5 to $+7^{\circ} \mathrm{C}$ & A2, ICTP-RegCM3 & For Summer Season & \multirow[t]{2}{*}{ Sen et al., 2012} \\
\hline & $+3.5^{\circ} \mathrm{C}$ & & For Winter Season & \\
\hline \multirow{2}{*}{$\begin{array}{l}\text { The Aegean Region } \\
\text { (Western Turkey) }\end{array}$} & +5 to $+6^{\circ} \mathrm{C}$ & $\mathrm{A} 2$ & For Summer Season & \multirow[t]{2}{*}{ Önol, Ünal, \& Dalfes 2009} \\
\hline & +2 to $+3^{\circ} \mathrm{C}$ & & For Winter Season & \\
\hline \multirow{3}{*}{ Turkey } & +1.0 to $+2{ }^{\circ} \mathrm{C}$ & RCP 4.5, and RCP 8.5 & $2016-2040$ & \multirow[t]{3}{*}{ Demircan et al., 2017} \\
\hline & +1.5 to $+4{ }^{\circ} \mathrm{C}$ & & $2041-2070$ & \\
\hline & +1.5 to $+5^{\circ} \mathrm{C}$ & & 2071-2099 & \\
\hline World & +1.5 to $+2{ }^{\circ} \mathrm{C}$ & SR 1.5 & 2100 & IPCC, 2018 \\
\hline
\end{tabular}

some plant groups, which do not demand higher temperature and distributed in mountainous areas, will be negatively affected.

According to the RCP 4.5 scenario, the end of the vegetation date of the western part will extend to the end of November. Similarly, the vegetation period will last until the first half of November in most of the areas outside the highlands of the mountainous areas in the eastern part. For mountainous areas, the vegetation period will end after the second half of October.

\subsubsection{Evaluation the Vegetation Period According to Climate Change Scenarios RCP 8.5}

When the vegetation period map according to the RCP 8.5 scenario for in the Inner West Anatolia Subregion is examined, it is seen that this map has more different characteristics according to others (Figure 5). The vegetation period will extend to 255-270 days (8.5-9.0 months) in the western part. This duration may also reach to 195-200 days (nearly 7 months) in the mountainous areas of the eastern part. Therefore, it can be foreseen that the vegetation may be a very significant change in the growing season. It is clear that this change may occur in the direction of the vegetation period being significantly extended.

In the Inner West Anatolia Subregion, the main areas of the prolonged vegetation period will be in the valleys and depressions. Especially in the western part, the marine impact may introduce to inner parts through the Gediz and Büyük Menderes valleys. These areas will be more suitable for evergreen species. Therefore, it can be assumed that species diversity of the maquis elements (Günal, 1986), which are inserted along the valleys, will increase further. Similarly, the vegetation period will increase by more than a month in the eastern part.

The western parts will be also the places of the first beginning of the vegetation period. From the west to the east, the beginning of the growing season may start nearly 10-15 days or 15-30 days later in the Demirci, Uşak, Sandiklı plains, and in the east, respectively. It is remarkable that in the western part, the vegetation activity will almost spread throughout the year, whereas in the eastern part, the end of the vegetation period may extend to the second half of October.

According to the RCP 8.5 scenario, the duration of the vegetation will extremely increase and plants, which are mostly of Euxine flora elements or spread in the mountainous areas, will reveal a change in terms of protecting their existence. Especially, Fagus orientalis, Quercus frainetto, Tilia rubra subsp. caucasica, Taxus baccata, Corylus colurna, Cornus mas, Vaccinium myrtillus, Viburnum lantana and Rhamnus frangula are adapted to more temperate temperature and humidity conditions. It should be also necessary to monitor how climate change reflects on these and other plant species. Similarly, it should be evaluated 
how Pinus sylvestris, which spreads at the high altitude of the mountains and which demands cold conditions for its growth, will protect the sprawling area.

Although there are different variables for climate change, such as precipitation, seasonal precipitation, extreme conditions and temperature, in this study only the temperature effect on vegetation has been evaluated. Climate change in the future, the same as in the past, will be changeable. Then, other ecologically important varieties except from temperature may change, and ecological responses might be episodic or nonlinear (Nolan et al., 2018). For this reason, precipitation properties may be also investigated for determining a potential effect on vegetation change through climate change scenarios.

\section{CONCLUSION}

In the Inner West Anatolia Subregion, the mean annual temperatures are between $10^{\circ} \mathrm{C}$ and $14^{\circ} \mathrm{C}$. These temperatures are lower in the east and the north while higher in the south and the east. When the number of frost days has been evaluated, the frequency slightly increased from 1975 to 1991 while it has gradually decreased in the last three decades. On the other hand, the tropical night temperatures have not been observed in the eastern and northern areas. On the contrary, in the southern and eastern parts, tropical night temperatures tend to increase. Due to the warm temperature related to climate change, the distribution and development of plants will be negatively affected. Similarly, the duration of the vegetation period will be extended depending on increasing temperatures.

The vegetation period of the Inner West Anatolia Subregion according to the mean daily temperatures has been up to 225 days in some parts. The longest vegetation of the Subregion has been seen in the low areas in the western part. In the eastern part, this duration has generally ranged between 195-210 days or decreased to 165 days in the mountain areas. When the vegetation of the Inner West Anatolia Subregion has been evaluated with two different climate change scenarios (RCP 4.5 and RCP 8.5), it may increase by 15-20 days and 40 days, respectively. These increasing vegetation periods could change the plants distribution and variety.

Acknowledgments: We would like to thank the Turkish State Meteorological Service (Ankara, Turkey) for providing the climate data.

Conflict of Interest: On behalf of all authors, the corresponding author states that there is no conflict of interest.

Grant Support: The authors received no financial support for this work

\section{REFERENCES}

Ackerly, D.D., Cornwell, W.K., Weiss, S.B., Flint, L.E., Flint, A.L. (2015). A geographic mosaic of climate change impacts on terrestrial vegetation: which areas are most at risk?. PLoS One, 10(6), $\mathrm{e} 0130629$.

Ackerly, D.D., Loarie, S.R., Cornwell, W.K., Weiss, S.B., Hamilton, H., Branciforte, R., Kraft, N.J.B. (2010). The geography of climate change: implications for conservation biogeography. Diversity and Distributions, 16, 476-487.

Aksoy, H., Unal, N.E., Alexandrov, V., Dakova, S., Yoon, J. (2008). Hydrometeorological analysis of northwestern Turkey with links to climate change. International Journal of Climatology, 28(8), 10471060 .

Aktaş, H. (1992). Plant Geography of Middle Black Sea Region (Between Yeşilırmak-Melet stream and Kelkit valley). İstanbul University, unpublished $\mathrm{PhD}$ thesis, İstanbul (in Turkish).

Albek, M., Öğütveren, Ü. B., Albek, E. (2004). Hydrological modeling of Seydi Suyu watershed (Turkey) with HSPF. Journal of Hydrology, 285(1), 260-271.

An, S., Zhu, X., Shen, M., Wang, Y., Cao, R., Chen, X., Yang, W., Chen, J., Tang, Y. (2018). Mismatch in elevational shifts between satellite observed vegetation greenness and temperature isolines during 2000-2016 on the Tibetan Plateau. Global Change Biology, 24, 5411-5425.

Angert, A.L., LaDeau, S.L., Ostfeld, R.S. (2013) Climate change and species interactions: ways forward. Annals of the New York Academy of Sciences, 1297(1), 1-7.

Atalay, İ. (1994). Vegetation Geography of Turkey. Ege University, İzmir (in Turkish).

Avc1, M. (1990). Plant geography in the western of Lakes Region in Turkey. İstanbul University, unpublished $\mathrm{PhD}$ thesis, İstanbul (in Turkish).

Avc1, M. (1995). Plant communities and their distribution on the western part of the Lakes District, Review of the Department of Geography University of İstanbul, 2, 47-72.

Avc1, M. (1996). Relationships between climatic characteristics and vegetation on the western part of the Lakes District. Istanbul Üniversitesi Coğrafya Dergisi, 4, 227-264 (in Turkish).

Avc1, M. (1997). Forest remnants on the field between Karasu and Tuzla Stream. Istanbul Üniversitesi Coğrafya Dergisi, 5, 179-224 (in Turkish).

Avc1, M. (1998). Plant geography of Ilgaz mountains and its surroundings

I: Geographic conditions of plant cover. İstanbul Üniversitesi Coğrafya Dergisi, 6, 137-216 (in Turkish).

Darkot, B., Tuncel, M. (1995). Geography of the Aegean Region. İstanbul University, İstanbul (in Turkish).

Demircan, M., Gürkan, H., Eskioğlu, O., Arabac1, H., Coşkun, M. (2017). Climate change projections for Turkey: Three models and two scenarios. Türkiye Su Bilimleri ve Yönetimi Dergisi, 1(1), 22-43. 
Dönmez, Y. (1972). Physical Geography Around the Kütahya Plains. İstanbul University, İstanbul (in Turkish).

Dönmez, Y. (1985). Geography of Plants. İstanbul University, İstanbul (in Turkish).

Elibüyük, M., Y1lmaz, E. (2010). Altitude steps and slope groups of Turkey in comparison with geographical regions and sub-regions. Coğrafi Bilimler Dergisi, 8(1), 27-55 (in Turkish).

Engin, İ. (1992). Plant Geography of the area between DeğirmendereYanbolu creek and Harşit stream. İstanbul University, unpublished $\mathrm{PhD}$ thesis, İstanbul (in Turkish).

Erinç, S. (1984). Climatology and Methods. Istanbul University, İstanbul (in Turkish).

Erlat, E., Türkeş, M. (2017). Observed variations and trends in number of tropical nights in Turkey. Aegean Geographic Journal, 26(2), 95106 (in Turkish).

ESRI. (2013). ArcGIS 10.2 Environmental Systems Research Institute, Inc. Redlands, USA.

Fairbridge, R.W., Oliver, J.E. (2005). Lapse Rate. Encyclopedia of World Climatology. New York: Springer, 448-450.

Fortems-Cheiney, A., Foret, G., Siour, G., Vautard, R., Szopa, S., Dufour, G., Colette, A., Lacressonniere, G., Beekmann, M. (2017). A $3{ }^{\circ} \mathrm{C}$ global RCP8.5 emission trajectory cancels benefits of European emission reductions on air quality. Nature Communications, 8(1), 89.

Frederiks, T.M., Christopher, J.T., Harvey, G.L., Sutherland, M.W., Borrell, A.K. (2012). Current and emerging screening methods to identify post-head-emergence frost adaptation in wheat and barley. Journal of Experimental Botany, 63(15), 5405-5416.

Fujihara, Y., Tanaka, K., Watanabe, T., Nagano, T., Kojiri, T. (2008). Assessing the impacts of climate change on the water resources of the Seyhan River Basin in Turkey: Use of dynamically downscaled data for hydrologic simulations. Journal of Hydrology, 353(1), 33-48.

Günal, N. (1986). Plant Geography Between Gediz and Büyük Menderes. İstanbul University, unpublished $\mathrm{PhD}$ thesis, İstanbul (in Turkish).

Günal, N. (1997). Geographical Distribution, Ecological and Floristic Characteristics of Principal Tree Species in Turkey. Çantay Press, İstanbul (in Turkish).

Günal, N. (2003). Plant Geography of Upper Gediz Basin. Çantay Press, İstanbul (in Turkish).

Günal, N. (2013). Effect of climate on natural plant vegetation in Turkey. Acta Turcica Çevrimiçi Tematik Türkoloji Dergisi, V(1), 1-22 (in Turkish).

Güngördü, M. (1993). Plant geography of southern Marmara Region (part of west). İstanbul University, unpublished essay, İstanbul (in Turkish).

Inouye, D.W. (2008) Effects of climate change on phenology, frost damage, and floral abundance of montane wildflowers. Ecology, $89(2), 353-362$.

IPCC. (2007). "Contribution of Working Groups I. II and III to the Fourth Assessment Report of the Intergovernmental Panel on Climate Change" Climate Change 2007: Synthesis Report. Geneva, Switzerland.
IPCC. (2013). "Working Group I Contribution to the Fifth Assessment Report of the Intergovernmental Panel on Climate Change" Climate Change 2013: The Physical Science Basis. Cambridge University Press, New York, USA.

IPCC. (2018). Global Warming of $1.5^{\circ} \mathrm{C}$. An IPCC Special Report on the impacts of global warming of $1.5^{\circ} \mathrm{C}$ above pre-industrial levels and related global greenhouse gas emission pathways, in the context of strengthening the global response to the threat of climate change, sustainable development, and efforts to eradicate poverty (Eds. Masson-Delmotte, V., P. Zhai, H.-O. Pörtner, D. Roberts, J. Skea, P.R. Shukla, A. Pirani, W. Moufouma-Okia, C. Péan, R. Pidcock, S. Connors, J.B.R. Matthews, Y. Chen, X. Zhou, M.I. Gomis, E. Lonnoy, T. Maycock, M. Tignor, and T. Waterfield). https://www.ipcc.ch/site/ assets/uploads/sites/2/2019/06/SR15_Full_Report_Low_Res.pdf.

Kläring, H.P., Klopotek, Y., Krumbein, A., Schwarz, D. (2015). The effect of reducing the heating set point on the photosynthesis, growth, yield and fruit quality in greenhouse tomato production. Agricultural and Forest Meteorology, 214-215, 178-188.

Körner, C. (2015). Paradigm shift in plant growth control. Current Opinion in Plant Biology, 25, 107-114.

Leibundgut, H. (1970). Der Wald.Verlag Huber, Frauenfeld und Stuttgart.

Liu, Q., Piao, S., Janssens, I.A., Fu, Y., Peng, S., Lian, X., Ciais, P., Myneni, R.B., Peñuelas, J., Wang, T. (2018). Extension of the growing season increases vegetation exposure to frost. Nature Communications, 9(1), 426.

Lizana, X.C., Avila, A., Tolaba, A., Martinez, J.P. (2017). Field responses of potato to increased temperature during tuber bulking: Projection for climate change scenarios, at high-yield environments of Southern Chile. Agricultural and Forest Meteorology, 239, 192201.

Mathur, S., Agrawal, D., Jajoo, A. (2014). Photosynthesis: response to high temperature stress. Journal of Photochemistry and Photobiology B: Biology, 137, 116-126.

Mazurczyk, W., Lutomirska, B., Wierzbicka, A. (2003). Relation between air temperature and length of vegetation period of potato crops. Agricultural and Forest Meteorology, 118(3), 169-172.

Meinshausen, M., Smith, S.J., Calvin, K., Daniel, J.S., Kainuma, M.L.T, Lamarque, J.F., Matsumoto, K., Montzka, S.A., Raper, S.C.B, Riahi, K., Thomson, A., Velders, G.J.M., van Vuuren, D.P.P. (2011). The RCP greenhouse gas concentrations and their extensions from 1765 to 2300. PClimatic Change, 109(1-2), 213.

Mittler, R. (2006). Abiotic stress, the field environment and stress combination. Trends in Plant Science, 11(1), 15-19.

Nolan, C., Overpeck, J. T., Allen, J. R., Anderson, P. M., Betancourt, J. L., Binney, H. A., ... \& Jackson, S.T. (2018). Past and future global transformation of terrestrial ecosystems under climate change. Science, 361(6405), 920-923.

Önol, B., Ünal, Y.S., Dalfes, H.N. (2009). Modeling impacts of climate change scenario over Turkey. ITU Journal Series D: Engineering, 8(5), 169-177 (in Turkish). 
Özdoğan, M. (2011). Modeling the impacts of climate change on wheat yields in Northwestern Turkey. Agriculture, Ecosystems and Environment, 141(1-2), 1-12.

Ozkan, B., Akcaoz, H. (2002). Impacts of climate factors on yields for selected crops in the southern Turkey. Mitigation and Adaptation Strategies for Global Change, 7(4), 367-380.

Pauli, H., Gottfried, M., Grabherr, G. (2014). Effects of climate change on the alpine and nival vegetation of the Alps. Journal of Mountain Ecology, 7, 9-12.

Porter, J.R., Gawith, M. (1999). Temperatures and the growth and development of wheat: a review. European Journal of Agronomy, 10(1), 23-36.

Primault, B. (1992). Temperature data used to determine a theoretical start to forest tree growth in spring. Theoretical and Applied Climatology, 45(2), 139-143.

Şar, T. (2018). Vegetation period in the inner West Anatolia subregion and evaluation of climate change scenarios. İstanbul University, unpublished Master's thesis, İstanbul (in Turkish).

Scheiter, S., Savadogo, P. (2017). Ecosystem management can mitigate vegetation shifts induced by climate change in African savannas. EGU General Assembly Conference Abstracts 19:2076.

Schmid, M., Ehlers, T., Werner, C., Hickler, T. (2018). Effect of vegetation change on denudation: Landscape response to transient climate and vegetation cover. EGU General Assembly Conference Abstracts 20:13659.

Sen, B., Topcu, S., Türkeș, M., Sen, B., Warner, J.F. (2012). Projecting climate change, drought conditions and crop productivity in Turkey. Climate Research, 52, 175-191.

Svenning, J.S., Eiserhardt, W.L., Normand, S., Ordonez, A., Sandel, B. (2015). The Influence of paleoclimate on present-day patterns in biodiversity and ecosystems. The Annual Review of Ecology, Evolution, and Systematics, 46, 551-572.
Svenning, J.S., Sandel, B. (2013). Disequilibrium vegetation dynamics under future climate change. American Journal of Botany, 100(7), 1266-1286.

Van Vuuren, D. P., Edmonds, J., Kainuma, M., Riahi K.R., Thomson, A., Hibbard, K., Hurtt, G.C., Kram, T., Krey, V., Lamarque, J., Masui, T., Meinshausen, M., Nakicenovic, N., Smith, S.J., Rose, S.K., (2011). The representative concentration pathways: an overview. Climatic Change, 109, 5-31.

Werner, C., Johan, L., Manuel, S., Juan-Pablo, F., Todd, A.E. Thomas, H. (2017). Simulating vegetation dynamics in Chile from $21 \mathrm{ka}$ BP to present: Effects of climate change on vegetation functions and cover. EGU General Assembly Conference Abstracts 19, 16673.

Wu, D., Zhao, X., Liang, S., Zhou, T., Huang, K., Tang, B., Zhao, W. (2015). Time-lag effects of global vegetation responses to climate change. Global Change Biology, 21(9), 3520-3531.

Yano, T., Aydin, M., Haraguchi, T. (2007). Impact of climate change on irrigation demand and crop growth in a Mediterranean environment of Turkey. Sensors, 7(10), 2297-2315.

Y1lmaz, Ö. (2001). Vegetation of Afyon and its surroundings. Türk Coğrafya Dergisi, 37, 47-77 (in Turkish).

Zandalinas, S.I., Mittler, R., Balfagón, D., Arbona, V., Gómez-Cadenas, A. (2018). Plant adaptations to the combination of drought and high temperatures. Physiologia Plantarum, 162(1), 2-12.

Zhang, X., Yang, F. 2004. ETCCDI/CRD climate change indices. RClimDex (1.0). http://etccdi. pacificclimate.org (accessed 4 November 2018). 
